\title{
Evaluation and Challenging Environment Comforting Retail Management and Retail Market Performance in Albania
}

\author{
Prof. Assoc. Dr. Alba Robert Dumi ${ }^{1}$ \\ Ma. Zamira Sinaj2 \\ Prof. Assoc. Dr. Samuel Humbley S'eche ${ }^{3}$ \\ 1Dean of graduated School "Ismail Qemali"Vlora University, Albania \\ Email:besi.alba@yahoo.com \\ 2Master School"Ismail Qemali"Vlora University, Albania \\ ${ }^{3}$ Accounting International University, NY College \\ Ave Monte, New Lonngern 458, NY USA \\ Email:jillawseche@gmail.com
}

\section{Doi:10.5901/mjss.2014.v5n2p25}

Abstract

People interact with retailing every day in telephoning for a pizza to be delivered, ordering a sweatera Lands end catalog, or buying tickets to a concert.Retailing is so much a part of our everyday life that it is often taken for granted.People do not realize the sophisticated business managers make and the technologies they use to provide goods and services. The most important element of this reform in the public sector is the incentive related to the reformation of the public administration. This process is necessary to face the challenges and to have better services with few sources possible. The public services are oriented by the input. The structures and the organizational procedures are created in order to involve the employees and need efforts and contribution from them. In the public service department the results are considered as a product of the efforts and staff's capacities. Retail managers make many complex business decisions in selecting target markets, locating stores, determining what merchandise and services to offer, negotiating with suppliers and deciding how to price, promote and display the merchandise. They use state of the art technologies to respond quickly to changing costumer needs. Retailing is the business activities involved in selling products and services to the ultimate (final) consumer. Even in the best locations, such as the capital Tirana, or the coastal metropolis of Durrës, Vlora Shkodra, Fieri, Saranda there are fantastic bargains to take advantage of when it comes to buying Albanian real estate.

Keywords: Audience and target, Individual performance, Challenges, Strategic aims, Albenian market and retailing management, Administrative performance

\section{Introduction}

The retaling industry is going through a particular turbulent era in the recent years in Albania. Consumer needs and demographics are changing: new retail formats are replacing older, new technologies drastically affecting retail operation, the ownership retail chains is changing throught a wave of mergers. Source: (RIT Design orientit approach, 2009)

The latest report by the United Nations Conference on Trade and Development (UNCTAD) ranks Albania among the countries with highest performance index in the region for attracting Foreign Direct Investments (FDI) in 2012, according to media reports on Friday. According to the UNCTAD's 2012 report, Croatia tops the ranking of the countries in region for attracting FDI, with FDI inflows estimated at around 1,25 billion dollars, followed by Albania with 957 million dollars. Bosnia and Herzegovina ranks third with FDI inflows at around 633 million dollars, Montenegro with 609 million dollars, Serbia with 352 million dollars, Kosova 298 million dollars, Slovenia 145 million and Macedonia with 135 million dollars. www.alb.gov report

Albania's main policies over the past years have resulted in a liberalized economic framework and improved conditions for doing business and for attracting FDI. A retailer is a business that sells products and services to ultimate consumers. Aretailer is the final business in a channel of distribution that links manufacturers with consumers. Retailers buy products from manufacturers and wholesalers and resell the products to consumers. Retailers must work closely with their supplies to be assured of having the products their cunstomers want. 
From rural homesteads, to palatial urban apartments, there's property for sale in Albania to suit the needs of every potential investor, all at prices that can't be beaten - not even in neighbouring countries. Often, people think of retailing only as the sale of product in stores. However, retailing also involves the sale of services, such as overnight lodging in a motel, an examination by a doctor, a haircut, the rental of a videotape or a meal in restaurants.

\subsection{The world of retailing concepts and the role of management in distribution channel}

Organization of the distribution channel.In most distribution channels, the manufacturing, whole-saling and retailing activities are performed by independent firms. However same firms are vertically integrated. Vertical integration means that a firm performs more than one function in the channel.

Offering Assortments. Manufacturers specialize in producing specific types of product. If each of these manufacturers had its own stores that only sold its own products consumers would have to go to many different stores to buy groceries to prepare a single meal. Retailers offer an assortment of product and services to their customers. Buy offering an assortment, retailers enable their customers to choose from a wide selection of brands, designs and prices in one location. Gilbert A, Chuncill Jr, Boston Ma, 02116

This suggests that most cities are overdeveloped in the provision of traditional shopping centres, although it is worth noting that many Eastern European cities do not have traditional, functioning high street retail, thus allowing for greater shopping centre capacity. This aside, it does point to potential difficulties further down the line for owners of shopping centre space, in light of the inevitable growth of on-line retail. (Research forecast \& report 2011)

Exhibit 1: Competitive advantages and long term relation.Gilbert A, Chuncill Jr, Boston Ma, 02116

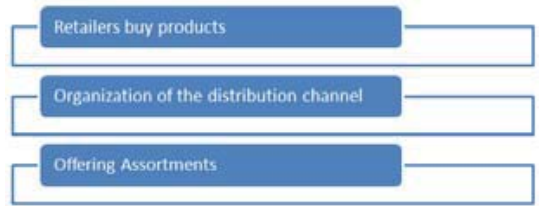

\subsubsection{Breaking bulk and Storing product}

To reduce transportation costs, manufacturers and wholesalers typically ship cases of frozen dinners or cartons of blouses to retailers and then the retailers provide the product in smaller quantities to meet consumer needs. A major function of retailers is to keep inventory so that product will be available when consumers want them. Gilbert $A$, Chuncill $\mathrm{Jr}$, Boston Ma, 02116

Thus consumers can keep a much smaller inventory of product, such as a tube of toothpaste or a half gallon of milk at home because they know the retailers will have the product available when they need more.

\subsection{Storing product and consumer behavior}

By maintaining an inventory, retailers provide a benefit to consumers they reduce the consumers cost of storing product First the investment to store products ties up consumers money that could be put in a bank account and earn interest ,or put to other use. Second the product can be damage or may spoil while they are being stored. Retailers also value to their merchandise by providing a variety of services. They offer credit so that consumers can have a product now and pay for it in the future. Gilbert A, Chuncill Jr, Boston Ma, 02116

They display product so that consumers can see and test them before making a purchase. Retailers may have salespeople available to answer questions and provide additional information about the product. Sane other retailer services include home delivery, gift wrapping, warranty coverage, repairs alterations and information for making comparisons between brands. (Dumi A, MCSER 2011)

\subsection{Increasing value of product and services and providing services}

The exciting field of retail management and fashion merchandising is flourishing with new opportunities to enhance customer service and discover new innovative ways to buy, develop and sell products. The evolution of the domestic and 
global retail marketplace and continuous advances in technology have created a multitude of options for consumers to receive goods and services without even leaving their front door. This requires retail management professionals to think outside the box along with having excellent decision and problem solving skills, impeccable customer service, and leadership skills to create a successful team. Source: Digital Retail Strategies, 2011

In our retail management program, you will receive a rigorous education to ensure you are ready to enter fields of buying, product development or store management. Retail Management graduates from Whitman are highly sought after by recruiters from Macy's, Bloomingdales, Kohls, Ross Stores, the TJX companies, Urban Outfitters and more. In addition, a newly developed concentration in Digital Retail Strategies is now available for retail majorsin conjunction with i-School. Above all, the program instills in its students a passion for implementing best management practices in the workplace, preparing them to become leaders in the field.

Fig 1: Source: Digital Retail Strategies, 2011httpischool.syre.edu, future underground

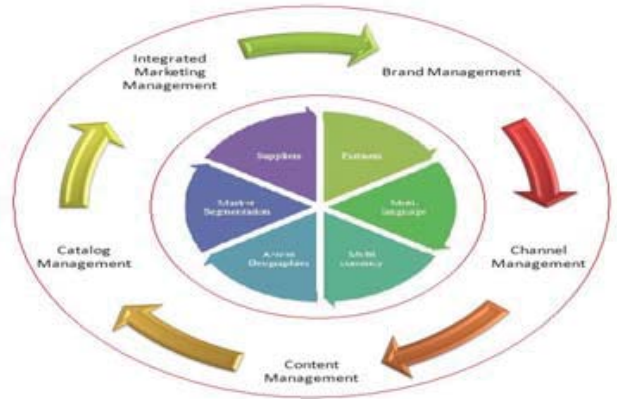

Offering assortments, breaking bulk, holding inventory and providing services, retailers increase the value consumers receive from their product and services. To illustrate, consider a side of beef in an lowa meat packing plant. This side of beef will not satisfy a family wants to buy a few steaks, from a barbecue for dinner time. (Van Fleet, D.D \& Yukl, G.A)

To satisfy the family s needs a supermarket cuts the side of beef into small portions. It sells the steaks in a conveniently located store that is open when customers are able to shop. The supermarket helps costumers select the steaks by displaying them so they can be examined before they are purchased. An employee is available to explain which steaks are best for barbecuing. The supermarket may even have a butcher on duty to provide special cuts of beef Finally the supermarket provides an assortment of other groceries potatoes, ears of corn and ice cream so that the family can buy the ingredients for an entire meal along with the steaks . Dumi A EJRM, 2011 USA

\section{Literature Review and Hypotheses}

\subsection{Retail management decision making process in South East Europe Countries}

In Bulgaria, several international fashion brands opened their first monobrand stores in shopping centers in Sofia - Liu Jo, Fornarina, Napapiji and Emporio -Armani. International discount operators in fashion, DIY and the sporting goods plan to expand in Bulgaria. Food retailers will continue expansion via convenience formats in key locations. Zaccaro, S.J, Foti, R.J \& Kenny, 1991

In Croatia, the Zagreb market witnessed the opening of one new shopping centre which brought $50,000 \mathrm{~m}^{2}$ to the market. The timing of this opening has been far from ideal, as falls in private consumption strongly (negatively) impacted retailer's trading performance. The result has been a softening of prime shopping centre yields to $8.5 \%$.

Fig 2 Source: Dumi A, EJRM, USA 2011 The impact of retailing management indicators.
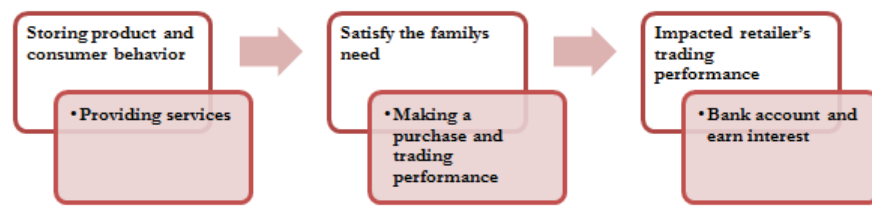


\subsubsection{Data and methodology of study in this paper research}

This article was made created by respecting all the methodological rules. The methodology of this article was based in two parts: Studying the foreign and Albanian literature, bibliographic studies, collecting data from official sources as Albanian Finance Institutions, ISSH Albania, MOF, and DRSKSH Vlora.Resources and from different publications such as magazines. And practicing, which is related with the interviews with leaders and employees of the Public Administration.

To collect the data for this article we made interviews, questionnaires and other researches. In Tirana, Albania no new supply was added to the retail inventory during 2012 as latent demand was previously absorbed by the opening of TEG (Tirana East Gate) at the end of 2011. Demand comprised renewals and sporadic requests from tenants needing new retail space. Source: Colliers International 2009)

We created also a questionnaire, which was composed by 30 questions and $4.8 \%$ of the employees in the central level of the public administration answered. We are concluding in these seven key factors for success, such as:

- Coherent links among urban planning, infrastructure and economic development

\begin{tabular}{|c|c|c|c|c|c|}
\hline & Indicator A & Indicator B & Indicator C & Indicator D & Criteria X \\
\hline First choice & 12 & 18 & 37 & 59 & 66 \\
\hline Second choice & 42 & 71 & 52 & 63 & 44 \\
\hline
\end{tabular}

The respective evaluations are presented below:

Graph 1: Source: The nature of a retail strategy, Dumi A EJRM, 2011 USA

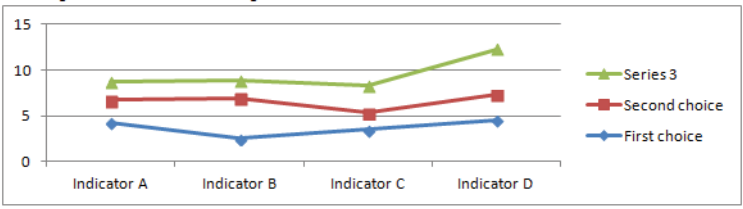

Store operations, play a critical role in implementing a retail strategy. Management decisions in this area attract customers to the merchandise, sell the merchandise and provide services to ensure customer satisfaction. An environment trend consists on these factors: The second factors in the situation analysis are environmental trends.

\subsection{Analyzing data and regression analyze}

The performance evaluation is mainly characterized by qualitative indicators and there are only a few quantitative indicators. According to the data collected from the questionnaires the employees asses the importance of the performance evaluation in $200 \%$, they concretize it with the objectivity in the evaluation.

\begin{tabular}{|c|c|c|c|c|c|c|c|c|c|}
\hline values & 4 & 4 & 5 & 6 & 7 & 7 & 7 & 8 & 9 \\
\hline Ranks & 1 & 2 & 3 & 4 & 5 & 6 & 7 & 8 & 9 \\
\hline
\end{tabular}

Seven of the thirteen major markets saw a change in rental market performance.

The retailer success depends largely on the degree to which it embraces the retailing concept. The retailing concept is a management orientation that holds that the key task of a retailer is to determine the needs and wants of its target markets and to direct the firm toward satisfying those needs and wants more effectively and efficiently than its competitors. The marketing concept indicates that retailers -in fact, all firms -should focus on satisfying consumer needs. The retailing concept broadens the scope of the marketing concept to consider competition. Gilbert A, Chuncill Jr, Boston Ma, 02116

It indicates that firms need to satisfy customers needs better than the competition does if they want to make a profit. 
Graph 2: Source: The nature of a retail strategy, Tomsonn 2011, EJRM USA, Dumi A EJRM, 2011 USA

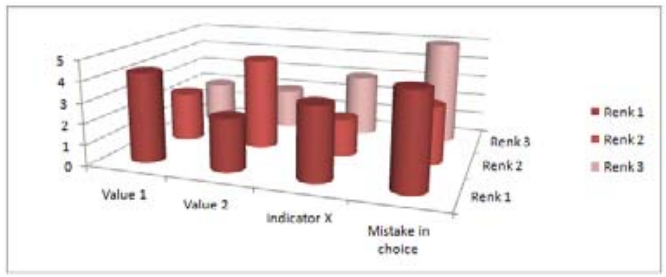

\subsection{Merchandise budget plan and develop promotional program}

Using information about consumers needs and buying behaviour, the retailer develops a merchandise assortment -the specific items to purchase. When selecting merchandise buyer decides how to price the items. Then they monitor the sales of merchandise to determine if prices need to be changed. Finally buyers work with people in advertising to develop promotional programs for their merchandise. The promoter program includes newspaper, radio, and television advertising, special promotions such as a garden sale and publicity for unique merchandise. Van Fleet, D.D \& Yukl, G.A

As a retailer enters the decade of the ' 90 they will confront a dynamic business environment. Customer needs are continually changing and the rate of change seems to be increasing. From a short implementation perspective a retailer needs to predict what items will be in demand for each season.

\subsubsection{Developing a retail strategy and calculate the Tomsonn criteria}

We calculate the quadratic average derivation of the Tomsonn criteria

$$
S_{R 1}=\sqrt{\frac{n 1 n 2(n 1+n 2+1)}{12}}+S_{R 2}=\sqrt{\frac{n 1 n 2(n 1+n 2+1)}{12}}+S_{R n}=\sqrt{\frac{n 1 n 2(n 1+n 2+1)}{12}} * \text { ZKn choices }
$$

To the question "Is the performance evaluation objective in your institution?"- $30 \%$ answered positively, $64 \%$ avoided the answer and $36 \%$ of them think that it is dictated from the subjectivity of the leaders. (Lako M, 2011)

According to the questionnaire the major part of the questioned employees think that the performance evaluation takes to conflicts between the subordinate and the superiors. This is also another factor that contests rewarding according to the performance. (Tomsonn 2011, EJRM USA)

We calculate the factual value $\mathrm{Zf}$ and compared with $\mathrm{Zk}$ that is the statistic value at a critic level.

$\mathrm{Zf}=\left(\mathrm{R}_{1 \mathrm{~m}}-\mathrm{MR}_{\mathrm{R}}\right) / \mathrm{SR}_{1}=(30-20) / 4.8=2$

$Z f>Z k 2>1.76$

Graph 3: Source: The nature of a retail strategy, Tomsonn 2011, EJRM USA, Dumi A. EJRM, 2011 USA

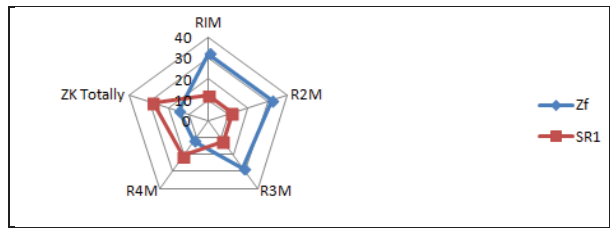

A retail strategy identifies the target market toward which the retailer will direct its efforts the nature of the merchandise and services the retailer will offer to satisfy the needs of the target market and how the retailer will build o long advantage over its competitors. The nature of a retail strategy can be illustrated by comparing the strategies of Wal Mart. Wal Mart identified its target marked as small town in Texas and Oklahoma.

It offered name brand merchandise at low in a broad of categories ranging from laundry detergent to girls dresses. While the Wal -Mart stores have many different categories of merchandise, the selection in each category is limited.

This suggests that most cities are overdeveloped in the provision of traditional shopping centres, although it is worth noting that many Eastern European cities do not have traditional, functioning high street retail, thus allowing for greater shopping centre capacity. This aside, it does point to potential difficulties further down the line for owners of 
shopping centre space, in light of the inevitable growth of on-line retail.( Van Fleet, D.D \& Yukl, G.A)

Exhibit 2: Performing situation analysis, Adverstising and indicator of performance Zaccaro, S.J, Foti, R.J \& Kenny, 1991

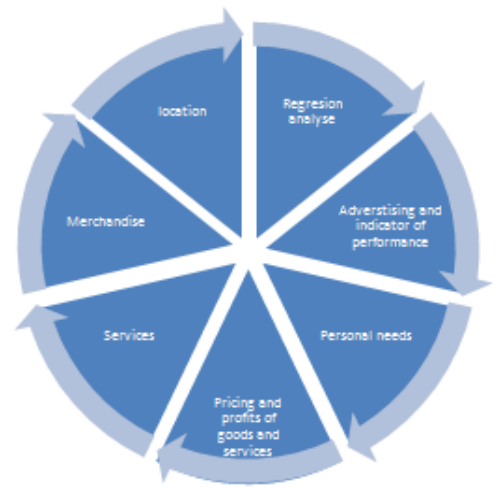

- Competition

- Environmental

- Customers

- Ethical and legal issue

\subsection{Developing retail strategy}

- Market strategy

- Financial strategy

- Retail organization

- Location strategy

2.5 Implementing retail strategy consist in "Merchandise management theory

Theory:

- Merchandise budget planning Managing store employees

- Assortment planning Customer service

- Pricing Retail selling

- Buying merchandise Store layout, design

- Retail promotion mix visual merchandise

\subsubsection{Integrated computer and distribution systems and Situation Analysis}

The first step in retail management decision process is performing a situation analysis. Retail managers need a good understanding of their environment, especially their customers and competition before they can develop and implement effective strategies. (Van Fleet, D.D \& Yukl, G.A)

In a situation analysis managers examine four environmental factors: 1. Competition 2. Environmental trends in consumer demographics and lifestile, technological developments and retail institutions. 3 The needs want and decision -making processes of retail consumers 4.Ethical and legal issues in developing indicators.

\section{Methodology and Research Goal}

From the long term strategic perspective, retailers need to respond to broad demographic and lifestyle trends in our society, such as the growth in the elderly segment of the U.S population ,importance of shopping convenience to the rising number of two-income families and shrinking of people interested in retail sales position . 
Customers are the third in the situation analysis. Retailing management, interact with customers on daily basis when customers do not find the merchandise they want or service they expect, they may leave a store without making a purchase. When they are dissatisfied with a product they bought they rarely complain to the manufacturer, they complain to the retailer that sold them the product. Even thought retailers have a lot of customer contact they frequently do not understand why customers buy or don't buy merchandise in their store. Zaccaro, S.J, Foti, R.J \& Kenny, 1991

\subsection{Location strategy}

Location is important for both consumer and competitive reasons. First location is typically the most important characteristic consumers consider when selecting a store. Generally consumers buy gasoline at the closest service station and patronize the shopping mall that is most convenient to their home or office. Second location offers an opportunity to gain a long term advantage over competition

\subsection{Merchandise management and store management}

Is the analysis of the general concepts of this paper research, planning, acquisition, promotion and control of merchandise sold by retailer? Merchandise management decisions are typically made by buyers who have a great deal of responsibility for determining what merchandise will be sold how it been sold.

Exhibit 3: Retail strategy development and implementation standarts. Zaccaro, S.J, Foti, R.J \& Kenny, 1991

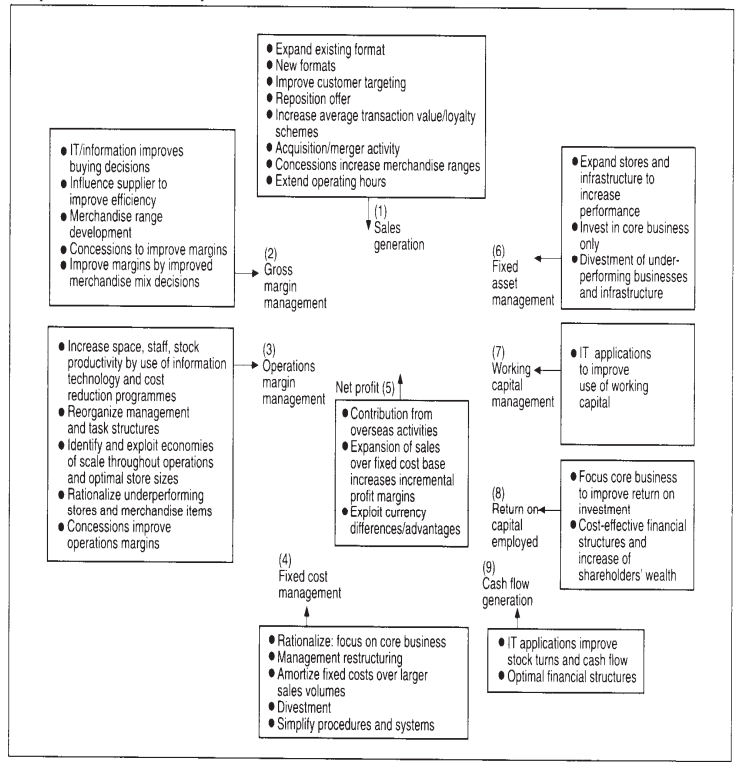

Exhibit 3 \& Fig 3: Retail strategy development and implementation standarts. Zaccaro, S.J, Foti, R.J \& Kenny,1991

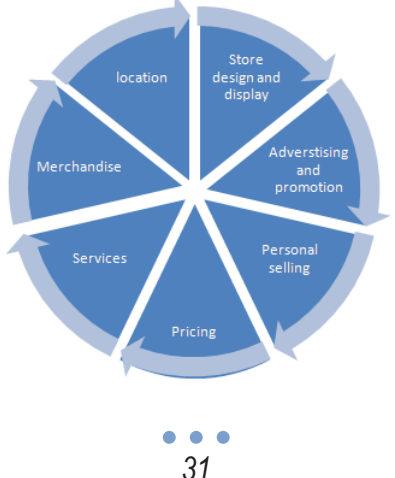


We recomanded these conclusions: Retailing management is labor-intensive industry a critical activity for store operations is managing people. Store management involves selecting, training, motivating and compensating employees in the store and minimizing losses due to customer and employees. The final aspect of the situation analysis is the ethical and legal environment in which the retailer operates. Philosophies and ethical standards guide management decisions, while legal and public policies restrict retail decision. Strategy development and implementation must be consistent with corporate values, legal opinions and public policies. (Van Fleet, D.D \& Yukl, G.A)

Federal state and local laws enacted to ensure that business activities are consistent with the interest of society. Same of these laws define unfair competitive practices related and restrict store locations. Retailers often use ethical standards to guide decisions making when confronting questionable situations not covered by laws.

Retail strategy management consists in steeps like this:

1. Using the situation analysis the next stage in the retail management decisions making process is formulating a retail strategy. The retail strategy indicates how the firm to focus its resources to accomplish its objectives. The key strategic elements are the market strategy the financial strategy the organizational structure and the location strategy.

Albanian government will focus in these indicators:

1. Introducing participatory planning and community-based development processes through neighborhood development committees and street representatives working in partnership with the city

2. Creating an enabling environment for private investment

3. Empowering citizens to pursue their own self improvement

4. promoting privatization of the housing a stock and fostering the development of micro- enterprises

5. Ensuring the sustainability of activities initiated

6. Promoting the reliability of successful initiatives.

Albanian government will be reality these points:

- A dynamic local government leadership

- A coherent strategy acted upon with determination

- A healthy climate of cooperation with business

- Local government's investment initiatives to jumpstart the stagnant economy

- Creative use EU funds to implement local policy

- Efficient municipal administration

\section{References}

Albanian Finance incomes 2009, pg 10, 45, Albania and reforming economy, www.economy Albania,com

An Overview of Public Administration in Albania pg 6 year 2008, THANASI Durata (Internet link)

Albanian publisher by Albania international bank 2010, report APA, net

Albania Government journal, pg 14, 27, 39 years 2009, Albania Economy statistic facts

Stogdill, R.M. personal factors associated with leadership: A survey of the literature. Journal of psychology, 1948/, 25, 35-71

The nature of a retail strategy, Dumi Alba \& Seche Samuel, EJRM, 2011 USA, 23, 45

Van Fleet, D.D \& Yukl, G.A. military leadership: an organizational behavior perspective. Greenwich, CT: JAI Press, 1986.

Vroom, V.H \& Yetton, E.W. Leadership and decision making Pittsburgh University Press, 1973

Wheaton, B. Assesment of fit in overidentified models with latent variables. In J.s. Long (Ed), Common problems/propers solutions: Avoiding error in quantitative research. Beverly Hills, CA: Sage, 1988.

Yukl, G.A. A New Taxonomy for Intergrating Diverse Perspectives, Managerial Behavior. Paper presented at the American Psychological Association meeting, New York, 1987.

Yukl, G.A. leadership in organization, Englewood Cliffs, NJ: Prentice-Hall, 1989. (a)

Zaccaro, S.J, Foti, R.J \& Kenny, D.A. Self-monitoring and trait-based variance in leadership: An investigation of leader flexibility across multiple team situations. Journal of Applied Psychology, 1991, 76(2), 308-315. 